\title{
Advances in the Cross-Linguistic Study of Ideophones
}

\author{
Mark Dingemanse* \\ Language \& Cognition Department, Max Planck Institute for Psycholinguistics
}

\begin{abstract}
Ideophones are marked words that depict sensory imagery found in many of the world's languages. They are noted for their special forms, distinct grammatical behaviour, rich sensory meanings, and interactional uses related to experience and evidentiality. This review surveys recent developments in ideophone research. Work on the semiotics of ideophones helps explain why they are marked and how they realise the depictive potential of speech. A true semantic typology of ideophone systems is coming within reach through a combination of language-internal analyses and language-independent elicitation tools. Documentation of ideophones in a wide variety of genres as well as sequential analysis of ideophone use in natural discourse leads to new insights about their interactional uses and about their relation to other linguistic devices like reported speech and grammatical evidentials. As the study of ideophones is coming of age, it sheds new light on what is possible and probable in human language.
\end{abstract}

\section{Introduction}

Ideophones are marked words depictive of sensory imagery found in many of the world's languages. They are noted for their special sound patterns, distinct grammatical properties, and sensory meanings. This review surveys recent developments in cross-linguistic research on ideophones. An attempt is made not to duplicate earlier typological reviews of ideophones (Blench 2010; Childs 1994; Diffloth 1972; Güldemann 2008; Kilian-Hatz 1999; Kulemeka 1995; Samarin 1971a; Watson 2001) or of sound-symbolism and iconicity (Ahlner and Zlatev 2010; Hinton et al. 1994; Jakobson and Waugh 1979; Nuckolls 1999; Perniss et al. 2010). The focus is on a number of topics that have remained underexplored and are being addressed in recent and ongoing work.

This review is also an argument for broadening the horizons and diversifying the research toolkit of ideophone research. For a long time, ideophone research has been preoccupied by a limited number of topics, the most prominent of which are phonology, morphosyntax, and sound-symbolism. ${ }^{1}$ Work on the meaning and use of ideophones has been much rarer. One could say that there has been a preoccupation with form not function. Yet in order to develop a complete understanding of ideophones, we need to take into account their rich sensory meanings, their interactional uses, and their place in the wider linguistic and cultural ecology (Ameka 2001; Childs 2001; Newman 2001). Ideophone research has much to gain from such diverse fields of inquiry as semiotics, psycholinguistics, semantic typology, corpus linguistics, conversation analysis, and the ethnography of speaking. These fields in turn may stand to profit from a renewed interest in ideophones as words relating language and sensory perception.

\section{Definition}

Ideophones have proven easy to identify, but difficult to define. The most widespread definition of ideophones is still Doke's (1935) semantic characterisation, which was 
however self-consciously limited to Bantu languages and which suffers from various other limitations (Dingemanse 2011a; Kulemeka 1994; Kunene 1965; Samarin 1971a). ${ }^{2}$ Since then, word classes identifiable as ideophones have been found in many of the world's languages. Indeed ideophony has been claimed to be a universal or near-universal feature of human language (Diffloth 1972; Kilian-Hatz 2001), although not all languages manifest it to the same extent (Liberman 1975; Nuckolls 2004). A proper definition of ideophones is essential as a reference point for cross-linguistic research and as a guide for understanding the forms of ideophones (Section 3), their sensory meanings (Section 4), and their interactional uses (Section 5). Following Dingemanse (2011a:25), ideophones are defined as marked words that depict sensory imagery. This definition is general by design, capturing the fundamental cross-linguistic characteristics of ideophones while leaving room for details and differences to be spelled out for individual languages.

Ideophones are MARKED in the sense that they stand out from other words. Claims about the marked nature of ideophones abound in the literature: ideophones are "very striking" (Vidal 1852:15 on Yoruba), "distinguished by their aberrant phonology" (Kruspe 2004:102 on Semelai), "structurally marked" (Klamer 2002:263 on Kambera), "phonologically peculiar" (Newman 1968:107 on Hausa), and show "distinctive phonology, involving special rules of length, tone, and stress" (Epps 2005:869 on Hup), to take just five typologically divergent languages from all over the world. Of course, what is marked in one linguistic system may not be marked in another. Exactly how the structural markedness of ideophones works out in a given language is a fact that belongs to the description of that language.

Ideophones are WORDS, that is, conventionalised items with specifiable meanings, as opposed to "simply sounds" (Okpewho 1992) or "[a] form that conveys an impression, not meaning" (Pei 1966). Although their meanings may be difficult to capture, they have been described in dictionaries from early on (Asano 1978; Blanchard and Noss 1982; Crowther 1852; Doke and Vilakazi 1953; Westermann 1905), and they have been studied using a variety of methods (Diffloth 1972; Nuckolls 1996; Samarin 1967a, 1970a) (and see Section 4 below). The fact that ideophones are conventionalised items in a language also explains that ideophone inventories often have language-specific signatures.

Ideophones are DEPICTIONS, that is, they are special in the way they signify their referents. This property can best be explained by means of an illustration. Consider the description "be walking with a limp" and the ideophone tyádityadi [tjáditjadi] from Ewe, with roughly the same meaning (Westermann 1907:83). The former DESCRIBES the way of walking whereas the latter DEPICTS it. The description consists of arbitrary signs, interpreted according to a conventional symbol system. The depiction tyádityadi - which in actual use would likely come with extra reduplication and intonational foregrounding - is a performance, inviting us to "look" in such a way that we make believe we are actually experiencing the scene depicted (see Section 3). The different mode of signification of ideophones has been captured by many terms, including "expressive/iconic" (Diffloth 1972), "affecto-imagistic" (Kita 1997), "performative" (Nuckolls 1995), and "mimesis" (Güldemann 2008). The term "depiction" is adopted here because it fits well with foundational work on ideophones, which characterized them as "Lautbilder" or "vocal images" (Werner 1919; Westermann 1927; Wundt 1922), and because it is recognised in a wide range of disciplines, including psychology (Bloom and Markson 1998; Kosslyn 1980), linguistics (Clark and Gerrig 1990), philosophy (Walton 1973; Zemach 1975) and aesthetics (Goodman 1968).

Finally, ideophones depict SENSORY IMAGERY: perceptual knowledge that derives from sensory perception of the environment and the body (Barsalou 1999; Paivio 1986). ${ }^{3}$ That 
ideophones have close ties to sensory perception has been recognised commonly and from early on in ideophone research (Fortune 1962:5; Junod 1896:196; Kita 1997:381; Koelle 1854:283; Noss 1986:243; Nuckolls 1995:146; Westermann 1907:129). The semantic range covered by ideophones differs from language to language (see Section 4), but often includes not just perceptions of the external world, but also kinaesthetic sensations, balance, and other inner feelings and sensations. "Sensory imagery" is intended to capture all of this.

A note on terminology: "ideophone" is the most widespread name for the phenomenon, in use since Doke (1935). Two other common terms are "expressive" (e.g. Carr 1966; Diffloth 1972; Wayland 1996) and "mimetic" (e.g. Akita 2009a; Kita 1997; Mester and Itô 1989), which have their roots in the prolific research traditions of South-East Asian and Japanese linguistics, respectively.

\section{Form}

Ideophones are conspicuous words. In the literature this has often been attributed in part to the occurrence of marginal speech sounds, but in actual fact this aspect is of minor importance. Most ideophones in a given language feature the regular phonemes of that language (Diffloth 1980; Newman 2001), and even if peculiar sounds occur, they tend not to be random points in phonetic space but bear a relation to the phonemic system of the language, for instance by filling gaps in the phoneme inventory (Diffloth 1980:57; Mithun 1982:51). What makes ideophones marked relative to ordinary words is not so much that they employ different sounds, but that they employ mostly the same sounds in a different range of possible configurations. Typical ways in which ideophones are structurally marked include skewed phonotactic distributions, various forms of feature harmony, most common among them vowel harmony (Akita et al. forthcoming; Blench 2010), and a restricted number of tonal melodies in tone languages. Ideophones also display certain liberties relative to other words: more possible syllable structures, a wider variety of word forms (often including several types of reduplication), and a remarkable susceptibility to expressive morphology - playful additive word formation processes like reduplication and lengthening (Zwicky and Pullum 1987). Expressive morphological processes do not apply indiscriminately to all ideophones in a language: in South-East Asian ideophone systems, different types of reduplication have subtly different semantic effects (Diffloth 1980), and in Siwu (a GTM, Kwa language from eastern Ghana), different processes of expressive morphology apply to different ideophonic word forms (Dingemanse 2011a).

The markedness of ideophones does not just play out at word-level but also in morphosyntax. Across languages, ideophones tend to show a great measure of syntactic independence: they tend to occur at clause edges rather than deeply embedded within them; they tend to be aversive to inflectional morphology; and they can be set off from the rest of the clause by a pause (Childs 1994; Diffloth 1972; Dingemanse forthcoming; Kunene 1965). These tendencies all underline the distinctiveness of the ideophonic sign (see Section 3.1 below). Güldemann (2008:282ff.) proposed two basic types of grammatical contexts in which ideophones occur: either (1) they occur "in more or less regular collocation with another content sign," or (2) "they establish (in a limited set of constructions) an event representation on their own" (2008:282). Both patterns are reported widely in the literature, and often they appear in the same language (Vidal 1852:15 for Yoruba; Alpher 1994:168 for Yir-Yoront; Kita 1997 for Japanese; Dumestre 1998:326 for Bambara; Newman 2000:249 for Hausa; Samarin 1970b:168 for Wolof; 
Bartens 2000 for various Atlantic creoles). The relation between the two is easy to see, as Alpher (1994:170) has pointed out: a very strong one to one collocational restriction of, say, verb and ideophone may make it possible to use the ideophone in a verbless context. Ideophones are often introduced using quotative markers or "say" or "do" verbs, emphasizing their depictive-performative nature. A threefold connection between ideophones, reported speech and gesture was noted by Kunene (1965) and has been documented in detail by Güldemann (2008) for a large sample of African languages. ${ }^{4}$ The connection is also attested outside of Africa. For instance in Classical Sanskrit, imitative words were followed by the quotative -iti according to Pāninini's 4th century BCE grammar (Pāninini 1962:196), and this same construction was used to mark reported speech and gestures (Whitney 1950[1889]).

Like the word-level features, these morphosyntactic features are cross-linguistic tendencies, not absolutes. Recent research has uncovered within-language variation at the level of ideophone types - a broad division between onomatopoetic ideophones and the rest, where the former tend to have a more peripheral syntactic realisation than the latter (Akita 2009a; Kilian-Hatz 1999) - and at the level of ideophone tokens - frequently used ideophones are more prone to undergo a process of deideophonisation (Dingemanse forthcoming). The morphosyntactic typology of ideophones within and across languages constitutes a major area for future research. Naturalistic corpus data is likely to play an essential role in this enterprise.

Summing up the discussion so far, the characteristic combination of liberties and limitations in ideophones results in a structural markedness that is easily mistaken for irregularity. Yet if ideophones flout the rules, it is in orderly ways. They form a coherent system of their own, building on the regular system but orthogonal to it (Diffloth 1980:50; Zwicky and Pullum 1987). They are made of the same material as ordinary words - the stuff of speech - but they use it in a different way.

\section{I. WHY IDEOPHONES ARE MARKED}

Why would ideophones be marked? A number of proposals have been put forward. The first is the COMPLEXITY proposal, associated with Klamer (1999, 2001, 2002). It holds that the marked phonology of ideophones reflects a correlation between semantic complexity and structural complexity. The proposal is not limited to ideophones but also includes proper names and swear words. Accordingly, it possibly overgeneralizes: the correlation between complex meanings and complex forms is an interesting one, but it glosses over the fact that there may be different reasons for the structural markedness of different types of words (Joseph 1997; Potts 2007; Zwicky and Pullum 1987). If we can be more specific about the reasons for the markedness of ideophones, this would be useful.

More specificity is offered by a second proposal, which holds that the form of ideophones is different because ideophones are iconic. We can call this the ICONICITY proposal. It is worded most clearly by Diffloth (1980:50), who defends the view that "every pattern found in Expressive phonology and absent in Prosaic phonology should have iconic value, and should be found in particular Expressives with precisely that value." According to the iconicity proposal, the marked structural features of ideophones exist because they have iconic value. This proposal accounts for the many instances of iconic mappings between form and meaning we find in ideophones. A problem is that it is not always easy to pinpoint the presumed iconic value of a structural feature. Is iconicity really the point of such ideophones as Japanese iya iya 'reluctantly' (Gomi 1989:9), Semai blb?al 'painful embarrassment' (Diffloth 1976:256) or Gbaya sélélé 'absolute silence' (Noss 
2001:263)? Many languages have considerable numbers of ideophones like this, i.e. words that are formally ideophones and yet appear not to be transparently iconic. How are we to handle such cases?

We can go back to early German research for a way out of this dilemma. Researchers like Wundt (1922:313) and Westermann (1927) characterised ideophones as Lautbilder or vocal images. Their insight was that in some fundamental respects, ideophones are more like images than ordinary words - in more modern terms, they are depictions. This is more about framing than about likeness. A crucial point about depictions is that they may vary in the degree to which they are lifelike, but that this does not stop them from being depictions. Compare Van Gogh's Almond Blossom, Marchel Duchamp's Nu descendant un escalier, and Mondrian's Victory Boogie Woogie. These paintings show different degrees of perceived resemblance to reality, but they are all presented and interpreted as depictions - as shown by the fact that viewers tend to ask even of the abstract Mondrian what it represents, rather than, say, read it as Morse code. Something similar holds for ideophones: the Gbaya ideophones dododo 'thunder', zananana 'blazing fire' and sélélé 'absolute silence' (Noss 2001:263) show different degrees of iconicity (perceived resemblance to events) but they are united in being presented and interpreted as depictions. It is useful, then, to think of ideophones first and foremost as depictions, and only in the second instance as iconic words. Depiction foregrounds speaker intent and mode of signification, whereas iconicity focuses only on the putative resemblance between sign and object.

Here another good reason for the structural markedness of ideophones comes into view. As spoken words, ideophones are part of the linear, temporally unfolding speech stream. To come to be regarded as depictive performances, they somehow have to be marked as different from the descriptive material in the speech stream. What better way than structurally marked forms and performative foregrounding? Just like we distinguish a line drawing from writing by its use of material (black lines represent shading and outlines instead of spelling out arbitrary characters) and by its framing (separating the drawing from the non-depictive surroundings), so we distinguish ideophones from ordinary words because of their use of verbal material (marked forms relative to ordinary words) and because of their performative foregrounding (setting them apart from the surrounding descriptive speech material). In the DEPICTIVE proposal, the structural markedness of ideophones is a signal of depictive status, an invitation to map sound onto sense (Dingemanse forthcoming; Kunene 1978, 2001; Nuckolls 1995, 1996). Compared with the other proposals, the depictive proposal is more specific, leaving open the possibility that other word classes may be structurally marked for different reasons; and it is more inclusive, explaining the common iconic mappings in ideophones without making them a required feature.

\subsection{HOW IDEOPHONES DEPICT: ICONIC MAPPINGS OF FORM AND MEANING}

If ideophones are depictions, how do they manage to depict sensory imagery in sound? Here again early German research provided the first steps. In particular, Westermann (1927, 1937) was one of the first to document some cross-linguistically recurrent iconic mappings in ideophone systems. He found that high tones, light vowels and voiceless consonants evoked smallness, clearness, and speed, and that low tones, dark vowels and voiced consonants evoked large size, dullness and slowness. He also noted that factors like reduplication, tone, vowel quality, vowel quantity, and muscle tension of consonants appeared to impinge on the meanings of ideophones. This line of work was continued 
by Diffloth $(1972,1976,1980,1994)$ in a series of studies of South-East Asian ideophone systems. Diffloth found that ideophones employ not just acoustic symbolism but also articulatory symbolism, where articulatory gestures are available for iconic mappings. For instance, Semai gepgwep depicts "the opening and closing of a cockle-shell" (Diffloth 1972:444). Articulatory symbolism in ideophones has been little studied so far. Work on synaesthesia and cross-modal mappings between sensory and motor areas (Ramachandran and Hubbard 2001), on the link between ideophones and embodied cognition (Akita 2010; Osaka and Osaka 2005), and on the role of oral gestures in speech perception (Yeung and Werker 2011) foreshadows important directions for future research.

The form-meaning mappings found in ideophones fall into three non-exclusive types of iconicity: IMAGIC ICONICITY, in which the sound of the word mimics a sound in the world; GeSTALT ICONICITY, in which word structure depicts event structure; and Relative ICONICITY, in which related forms map onto related meanings (Dingemanse 2011b). One can think of these three types of iconicity as a toolkit for depiction in language - a toolkit which also enables the creation and interpretation of new ideophones. Imagic iconicity is usually of limited importance in ideophone systems: only a small part of the ideophone inventory tends to be imitative of sound. It is the diagrammatic types of Gestalt and relative iconicity that enable ideophones to move beyond the imitation of singular events toward cross-modal associations, perceptual analogies and generalisations of event structure (as we see in Section 4.2). A recent description of an intricate system of relative iconicity is provided by Tufvesson (2011), who shows how iconic mappings in Semai tie together sensory experiences and enable the encoding of gradient perceptual experiences by gradient linguistic forms.

Although Westermann's early work on sound-symbolic mappings in ideophones was contemporaneous with the foundational experimental studies of sound-symbolism by Köhler and Sapir (Köhler 1929; Sapir 1929), for a long time these two threads were effectively insulated from each other. Ideophone researchers diligently described soundsymbolic patterns in ideophone inventories (e.g. Awoyale 1983; Collins 1979; Diffloth 1972; Henderson 1965; Maduka 1988) while experimental studies focused on testing normal or nonce words mostly in non-ideophonic languages (e.g. Brown and Nuttall 1959; Brown et al. 1955; Davis 1961; Marks 1978; Weiss 1964). In recent years there has been a rapprochement in that more studies of ideophones take into account the wider literature on sound-symbolism, and use controlled measures to test claims about form-meaning mappings. For instance, Gasser et al. (2010) measured correlations between form similarity and meaning similarity and showed that ideophones in Japanese and Tamil exhibit more relative iconicity than do concrete nouns in these languages. Imai et al. (2008) showed that sound-symbolism facilitates the learning of verbs constructed on the template of Japanese ideophones. Akita (2009a) investigated sound-symbolic interpretations of ideophones and non-ideophones, finding among other things that subjects were more inclined to 'see' magnitude symbolism in ideophone-like novel words, especially when they were presented in an ideophonic construction (i.e. presented as depictions).

Despite these promising developments, there is still an all too common assumption in research on sound-symbolism that ideophones and other sound-symbolic words do the work of representation simply by phonetic means - that is, that the meaning somehow resides in the form itself, and that we can get at it by studying the form in isolation (e.g. Osaka and Osaka 2005; Tedlock 1999). Little attention has been given to the role of conventionalisation and the attendant possibility of iconic regularities that are languagespecific (Diffloth 1994). Even less thought has been given to ecologically valid models of ideophone use and to the crucial role of the actual performance of ideophones. Yet as 
shown by Nuckolls (1996) and Dingemanse (2011a:174-83), the full depictive potential of ideophones is only unleashed in the actual performance, with speech rate, loudness, phonation type, and gestures all contributing to the iconic qualities of ideophones. In descriptive and experimental work, more attention to matters of performance and pragmatics will be necessary in order to fully understand how ideophones come to be produced and interpreted as vocal images: richly cross-modal depictions of sensory imagery.

\section{Meaning}

The sensory imagery depicted by ideophones covers a broad range of perceptions, sensations, and inner feelings. Despite the significance of ideophones as dedicated sensory words (Dingemanse and Majid 2012), research on their meanings has been sparse. The work of William Samarin $(1965,1967 a, b): 164-8$, Samarin $(1970 a, 1971 b, c)$ is one of the shining exceptions, but his methodological contributions have received surprisingly little following. Indeed, a common move in many studies of ideophones has been to acknowledge the elusive and challenging nature of the meanings of ideophones and then move on to more tractable areas.

Table 1 samples the semantic diversity of ideophones in seven typologically divergent languages, demonstrating the wide range of meanings covered by ideophone systems across the world. Confronted with the semantic diversity sampled here, a number of questions arise. What is the range of variation? Do ideophone systems across languages systematically differ in the range of meanings they cover? Are there reliable ways of charting the territory of sensory imagery and measuring how the meanings of ideophones are distributed over it? Such questions are essentially questions of semantic typology (Evans 2010; Pederson et al. 1998).

\section{I. SEMANTIC TYPOLOGY OF IDEOPHONES}

Developing a semantic typology of ideophones requires classifying and comparing meanings. It is useful to consider some of the ways in which this has been done before. Alexandre (1966) classified the ideophones of Bulu, a Bantu language of Cameroon, into three categories: (A) ideophones that evoke a sensory perception (auditory, visual, tactile, gustative, or olfactive); (B) ideophones that illustrate or evoke the behaviour of animate entities (physical and moral); (C) ideophones that illustrate the aspect, state etc. of diverse objects (movement, situation, position, aspect). Here a problem surfaces: Alexandre's classification may reflect the preoccupations of own his time and metalanguage more than the structure of the language under study. For instance, significant parts of his B and C categories can in fact be subsumed under a broader conception of sensory perception, widely shared in modern-day work on the senses (Schiffman 1990; Sekuler and Blake 2002); and the five-fold subdivision of his A category simply reproduces the five senses folk model of French (for a similar classification in German, see Kilian-Hatz 1999:33-35). Yet given the formidable variety in cultural constructions of perception (Classen 1993; Geurts 2002; Howes 1991; Majid and Levinson 2011), we cannot assume that Western folk models of perception are universally applicable to the classification of ideophones.

Let us look at another approach to categorizing ideophones. Samarin (1965) classified the ideophones of Gbeya, an Adamawa-Ubangi language spoken in the Central African Republic. He reported: "I have had considerable success with 15 components: appearance, arrangement, emotion, measure, motion, odour, quality, shape, sound, state, taste, temperature, time, touch, and weight." (Samarin 1965:119; similar classifications are 


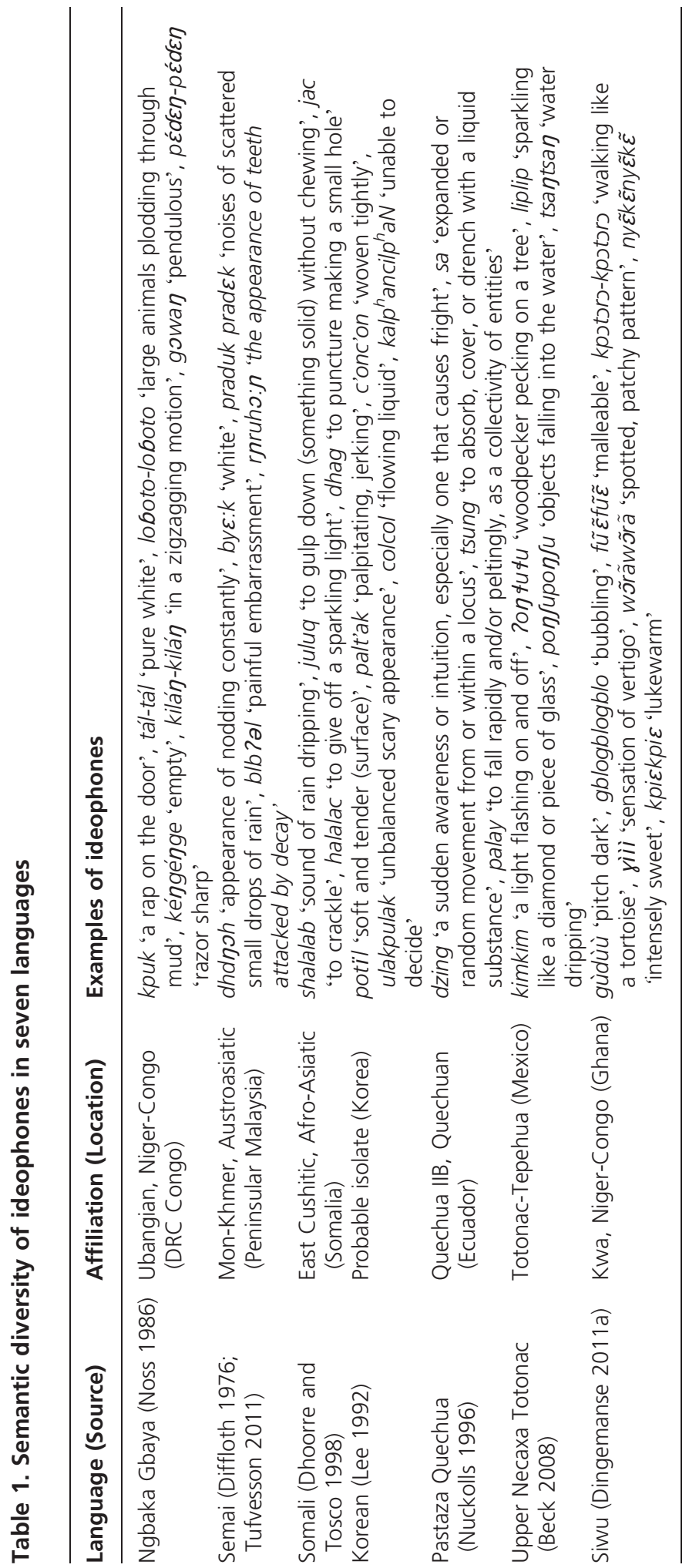


found in Awoyale 1983:16-21; Dhoorre and Tosco 1998:131ff.; Watson 2001:394-5). Samarin's categories are considerably more fine-grained than Alexandre's. Still, without an independent metric, it is unclear whether we are not just trading French distinctions for English dimensions. Moreover, comparing the classifications by Alexandre and Samarin, another problem becomes apparent: that of reproducibility. If two analysts arrive at such different classifications, how can we compare the systems?

These are classic challenges in semantic typology. They are best addressed with a twopronged approach. The first line of attack is from within the system itself: avoid importing preconceived categories and try to work out the salient distinctions made in the system. This is best done using methods appropriate to the task of charting the diversity and preferably relying not just on analysts' judgements but also on native speaker knowledge. Several methods for the system-internal (emic) analysis of ideophones are available. Samarin (1967a, 1970a) described methods like paraphrasing ideophones and investigating lexical relations (synonyms and antonyms). Diffloth (1976) observed that we can learn about the sensory semantics of ideophones by seeing how they combine with verbs of sensory perception; in a similar vein, Awoyale (1983) advocated combining collocational evidence with paradigmatic relations among ideophones and formal features like tone patterns and reduplication to identify semantic domains. Nuckolls (1996:145-275) employed a large corpus of ideophones in stories and interviews to describe their meanings in great detail. Dingemanse described a procedure for the collection of folk definitions of ideophones (Dingemanse 2010), and a pile sorting task which can be used to map the semantic structure of the domain on the basis of native speaker judgments (Dingemanse and Majid 2012).

The second line of attack is to use language-independent metrics to compare ideophone systems across languages. One way to do this is stimulus-based elicitation, in which non-linguistic stimuli are used to elicit linguistic responses. If our stimuli cover a certain etic grid or conceptual space, we can think of the responses as points located in this space, and we can compare the distributions of responses across languages to develop a typology of the meanings of ideophones. Methods like these have been much rarer in ideophone research, and yet they are absolutely crucial for cross-linguistic comparison. Samarin's (1967a:39) use of a brush as a stimulus for elicitation is an informal precursor. More recently, Tufvesson (2007) compiled a set of acoustic and visual stimuli for eliciting ideophones, and Dingemanse (2011a:189-205; 2011c) showed that ideophones can be elicited using a set of elicitation tasks designed to investigate how languages encode perception (the "Language of Perception" tasks, Majid and Levinson 2007). More languageindependent methods like these are urgently needed.

The strength of any semantic typology depends on the combination of both emic and etic perspectives. Without an emic perspective, we risk overlooking relevant dimensions of variation. Without an etic grid, or a shared conceptual space, comparison across languages becomes impossible. The way forward for the cross-linguistic semantic typology of ideophones, then, is to adopt multiple methods, combining detailed lexicographic fieldwork with sorting tasks, collections of folk definitions and stimulus-based elicitation. Only then will we be able to map and compare the full diversity of ideophone systems across languages.

\subsection{AN IMPLICATIONAL HIERARCHY}

The semantic typology of ideophones is still in its infancy, but if we permit ourselves to draw in broad strokes some observations can be made. Ideophone systems differ quite substantially in the semantic areas they cover (Kilian-Hatz 1999:31-52). There appear to 
be languages whose ideophone systems are limited to ideophones imitating sound (onomatopoeia). An example may be Navajo (Southern Athabaskan, Reichard 1950; Webster 2008a). More commonly, ideophone systems extend a bit beyond onomatopoeia by also including depictions of movement, often combined with sound. Examples from Table 1 above are Pastaza Quechua and Upper Necaxa Totonac. Other ideophone systems cover an even wider range of sensory imagery, including not just depictions of sound and movement but also of visual patterns, shapes, tastes, textures, inner feelings, and so on. Examples from Table 1 above are Korean, Semai, and Siwu.

Two observations can be made here. First, there appear to be areal biases. For instance, judging by the extant literature (the caveat is crucial, since most studies are based on small and opportunistically collected samples of ideophones ${ }^{5}$ ), ideophone systems from the Americas appear to be mainly limited to encoding sound and movement (Nuckolls 1996; Tedlock 1999); African ideophone systems tend to cover broad ranges of sensory imagery (Samarin 1971a); and Japanese and Korean have been reported to feature relatively high numbers of ideophones for cognitive states (Akita 2009a; Childs 2001). If such broad tendencies - if indeed they are tendencies - are investigated in more detail, we will be able to better trace the development of ideophone systems and the role of cultural transmission (both horizontal and vertical) in shaping them.

The second observation is that there is a certain logic to the constitution of ideophone systems. While some are limited to ideophones depicting sound (onomatopoeia), others extend beyond that to movement and to other sensory modalities, and yet others even include inner feelings and psychological states. At the same time, some logically possible systems do not seem to occur. For instance, there are no reports of languages with ideophones for textures or inner feelings which do not also have ideophones for sounds and movements. This allows us to construct the implicational hierarchy in (1) (cf. Akita 2009a:20-32; Kilian-Hatz 1999:35-41):

(1) SOUND < MOVEMENT < VISUAL PATTERNS $<$ OTHER SENSORY PERCEPTIONS $<$ INNER FEELINGS AND COGNITIVE STATES

The way to interpret this implicational hierarchy is as follows: if a language has ideophones at all it will have at least ideophones for sound (i.e. onomatopoeia). If a language has ideophones for movement it will also have ideophones for sounds. If a language has ideophones for visual patterns (e.g. spatial configuration or surface appearance), it will also have ideophones for movements and sounds, et cetera. Conversely, a language that does not have ideophones for sounds or movements will not have ideophones for cognitive states. ${ }^{6}$

Why is the hierarchy ordered the way it is? This is likely the result of an interplay of multiple factors, including at least our sensory systems, the nature of sensory input from the environment, and the semiotics of depicting sensory imagery in speech (reviewed in Section 3.2). Sound is common and highly salient for humans, and to depict it in speech we can use the simplest kind of semiotic mapping, imagic iconicity, in which sound is depicted with sound. Movement frequently comes packaged together with sound in sensory input, and to depict movement events, we can use not just sound but also the suprasensory attributes of speech, for instance intensity and aspectual structure (Marks 1978). This is where Gestalt and relative iconicity come in: we can use reduplication to suggest repetition and the vowel space to suggest different grades of intensity. From there, VISUAL PATTERNS like spatial configuration and surface appearance can follow: these are also commonly observable and relatively salient, and even if they do not involve 
sound, they do share with speech some of the suprasensory attributes (e.g. intensity and aspectual structures such as iteration and durativity). The same holds for OTHER SENSORY PERCEPTIONS like texture and taste: although these may be somewhat less directly observable, again they share with speech some suprasensory attributes and therefore can be depicted using Gestalt and relative iconicity. That state may finally function as a springboard to extend the idea of depiction to imagery that is the least directly observable but that still shares some of the same suprasensory attributes: INNER FEELINGS AND COGNITIVE STATES. Importantly, all states naturally follow from each other, and the latter are not likely to arise without the former being in place - the hallmark of an implicational hierarchy.

The implicational hierarchy of ideophone systems proposed here is consistent with the cross-linguistic data currently available, but as more data comes in (and here the methods for semantic typology outlined above are crucial), we will be able to refine it in two ways. First, it is likely that finer distinctions can be made. For instance, in time it should be possible make further distinctions in the class of "other sensory perceptions." Second, when we have grounds to make finer distinctions we may well find that the implicational hierarchy does not take the shape of a simple linear sequence but of a more multi-faceted semantic map (see e.g. Van der Auwera and Temürcü 2006) with multiple possible trajectories of semantic extension and change. These trajectories should be traceable in ideophone systems around the world. Describing them will shed light on the genesis and evolution of ideophone systems, as well as lead to a better understanding of the relation between language and perception. It will also contribute to a more general typology of mimesis in language, an enterprise with relevance to the study of verbal art and language evolution (Davidson and Noble 1989; Donald 2005; Güldemann 2008).

\section{Use}

Early ideophone researchers commented on the commonality of ideophones in everyday conversations and narratives (Junod 1896; Westermann 1907; Whitehead 1899). As Whitehead wrote, "These words are the most graphic in the language, they are the "colouring' words, the stories and common speech of the people are full of them" (Whitehead 1899:18). Despite these early observations, the next century of ideophone research was to background "common speech" and foreground "stories" as the locus of ideophone use. Burbridge (1938) for example only focused on their use in highly emotional stories, and the Doke saw ideophones as a dramatic rhetorical device (Doke 1948:287). One of the legacies of Doke's foundational work is a broad consensus today that ideophones are most typical of an "informal language register" and that their main function is "to dramatise a narration" (Kilian-Hatz 2001:156; for similar views, see Doke 1948; Fortune 1962; Frieke-Kappers 2007; Kilian-Hatz 1999:23-30; Kunene 1978; Nuckolls 1996; Okpewho 1992; Yankah 1984, inter alia).

Why would the narrative be an important locus of ideophone use? A probable reason is that one of its main goals is to let the listener know what it was like to experience the events reported (Cassell and McNeill 1991; Stivers 2008). Such a goal invites the liberal use of depictive devices like ideophones and gestures - devices that bring to life the narrated events in ways that ordinary words do not. However, before we identify ideophones with tools for telling gripping stories, we need to ask: is the narrative really the main locus of ideophone use? Judging from the preoccupations of much of the existing literature, one would guess they are. But here we have to recognize a possible confound. The narrative monologue has long been one of the favourite data 
sources for field linguists: simple to elicit, clearly bounded, and relatively easy to transcribe and translate. Our default assumptions about the uses of ideophones are based on this limited data sample. We would do well to look further before settling on an answer.

\section{I. BEYOND NARRATIVE: SPECIAL GENRES AND EVERYDAY SPEECH}

The goals of a typology of ideophone use are twofold: finding out how ideophones are used across different ways of speaking, and why they are used in this way. In recent years, there has been an increased recognition of the need to investigate ideophones in genres other than narratives. Examples include studies by Mphande (1992) on ideophones in African verse, Klassen (1999) on Shona Ngano song performances, Mous (2000; Mous and Sanka 2007) on Iraqw riddles, Lydall (2000) on Hamar ritual prayers, Samarin (1969) on Gbeya insults, Noss $(1975,1989,2001)$ on written poetry and ideophone poems in Gbaya, Dingemanse (2009, 2011a:301-25) on greeting routines and funeral dirges in Siwu, and Webster (2008b, 2009) on Navaho written poetry. These authors find that ideophones serve many different uses, some of them highly poetic, some more prosaic. We learn little by summarizing these uses as "dramatic" or "rhetoric." Instead, we need to find out what it is that makes ideophones suitable for these varied genres.

Most of the moves away from the exclusive focus on narrative have been towards quite specific genres of verbal art. The natural complement would be to investigate how ideophones are used in everyday speech, that basic stream of verbal behaviour that underlies all other ways of speaking (Levinson 1983; Schegloff 2006). This is not a new idea: it harks back to early authors like Junod, Whitehead and Westerman, who already observed that ideophones are especially common in everyday speech. For various reasons however, from technological challenges to assumptions that conversational data is too disorderly to study, the investigation of ideophones in corpora of natural speech has commenced only recently.

Working with a video corpus of naturally occurring conversations in Siwu, Dingemanse $(2011 \mathrm{a}, \mathrm{c})$ found that ideophones are ubiquitous in everyday speech, and that, contrary to the received view, they are not limited to stories, dramatic speech styles or to situations of conviviality and high involvement. The use of ideophones in the Siwu corpus showed a great sensitivity to epistemic matters like source of knowledge and relative rights to deliver assessments. For instance, Siwu speakers were found to use ideophones as appeals to personal experience in cases of providing evidence or displaying their expertise. Listeners were found to echo ideophones to display social affiliation, but only in cases where the topic did not intrude on territories of knowledge that could be considered private (Dingemanse 2011a:288-97). Far from being mere stylistic flourishes, ideophones were found to be a vivid and versatile communicative tool. Similarly, examining the use of ideophone-like "sensory words" in a corpus of informal Yucatec Maya conversations, Le Guen found that they contributed "to the accuracy of the description but also to the verification of speaker's understanding" (Le Guen 2011:124; cf. Nuckolls 1995).

Two lessons can be drawn from this kind of work. The first is a methodological one: if we want to learn more about the functions of ideophones, it may be more profitable to think in terms of the interactional work done with them rather than in terms of the contexts in which they occur. Ideophones do not mechanistically occur in some contexts and disappear in others: speakers choose to use them or not, and sequential analysis of actual records of conversation can reveal what is being accomplished in making such 
choices. The second lesson is that there are functions of ideophones that can only be seen in actual use - functions that have remained out of sight because of the field's focus on narrative. For instance, the connection with experience, epistemics and evidentiality suggests a fertile new area of research, in which lexical devices like ideophones are compared with grammatical systems of evidentiality (Chafe and Nichols 1986; Gipper 2011) and with interactional devices like reported speech (Clift 2006; Holt 1996) to see how different speech communities handle knowledge and evidence in social interaction.

A concerted research effort is needed to build a cross-linguistic understanding of the uses of ideophones, both in everyday speech and in more specialized genres. Working with naturally occurring speech is crucial and most urgent, as this will make it possible to catalogue the different uses of ideophones in everyday social interaction, a necessary baseline to understand all the other uses. Investigating more specialized ways of speaking is important as a way of charting the culturally situated performance styles (Nuckolls 2006) in which ideophones are used.

Even though some of the newly discovered uses of ideophones may be unexpected from the traditional point of view, they naturally follow from the defining characteristics of ideophones: their depictive mode of representation, as words that bring events to life (see Section 3), and the sensory nature of their meanings, as words that are intimately tied to perception and sensation (see Section 4). There is no doubt that new data will lead to refinements of the findings in this domain, but whatever other uses lie waiting to be uncovered, we can expect that they will similarly be grounded in the nature of ideophones as marked words that depict sensory imagery.

\section{Conclusions}

The sheer ubiquity of ideophones in the worlds' languages, from Japan and South-East Asia to Africa and from India and Turkey to South America, makes it clear that depiction in speech, and in particular, a class of marked words that depict sensory imagery, is a common feature of human language. This class of depictive words has its own distinct profile in every language, and yet there are also general properties that transcend the particulars. One of these properties, the structural markedness of ideophones, has long been a focus of research. Here this property has been connected to another fundamental characteristic of ideophones: their depictive mode of representation.

Recent developments bring a welcome widening of perspective as ideophone research starts to reap the benefits of the broad range of methods available in linguistics and neighbouring disciplines. Descriptive and experimental work on iconicity unravels the depictive potential of speech, both in its universal and language-particular properties. Semantic typological work on the meanings of ideophones enhances our understanding of how natural languages encode sensory imagery, and uncovers an implicational hierarchy of ideophone systems. Work on the use of ideophones shows the necessity of looking beyond narrative monologues to special ways of speaking and to rich corpora of language in use, and uncovers how ideophones are used to share in perceptual experiences and to sort out matters of evidence and epistemic primacy. As the study of ideophones is coming of age, it sheds new light on what is possible and probable in human language.

\section{Short Biography}

Mark Dingemanse is a research staff member at the Max Planck Institute for Psycholinguistics. His research interests include the study of meaning as it emerges in situated interaction, the relation between everyday language and verbal art, and the interplay of language, culture, and cognition. 


\title{
Acknowledgement
}

I am grateful to Felix Ameka, Gunter Senft, and two anonymous reviewers for their comments on earlier versions of this article. This work was supported by the Max Planck Society for the Advancement of Science and the European Research Council (grant HSSLU).

\author{
Notes \\ * Correspondence address: Mark Dingemanse, Language \& Cognition Department, Max Planck Institute for \\ Psycholinguistics, Wundtlaan 1, Nijmegen, 6525XD, Netherlands. E-mail: mark.dingemanse@mpi.nl \\ 1 This is easily seen by reviewing the topics of ideophone-related doctoral dissertations in the period 1975-2010: \\ virtually all fall in the domains of phonology and morphosyntax (Childs 1988; Kim 1984; Kulemeka 1994; McFar- \\ land 2009; Mphande 1989; Sien 1997; Sohn 1987), often combined with sound-symbolism and phonosemantics \\ (Baronti 2001; Ciccotosto 1991; Crisfield 1978; Fordyce 1988; Hamano 1986; Lee 1992; Magnus 2001; Mok \\ 2001). Singular exceptions are Klassen (1999), an intricate analysis of ideophone and gesture in a Shona ngano tale, \\ and Akita (2009a), a typologically informed study of the Japanese ideophone system using experimental methods \\ and corpus data. \\ 2 Doke's definition is: "A vivid representation of an idea in sound. A word, often onomatopoetic, which describes \\ a predicate, qualificative or adverb in respect to manner, colour, sound, smell, action, state or intensity." \\ 3 Despite the visual origin of the term, "imagery" is not to be understood as exclusively or even primarily visual in \\ nature. Here as in the psychology literature it refers to perceptual knowledge grounded in experience in a broad \\ sense. \\ ${ }^{4}$ In light of the affinity between ideophones and other types of depictive demonstrations like reported speech \\ (Clark and Gerrig 1990), the observation that ideophones are commonly found in declaratives (Childs 1994) and \\ appear to be incompatible with questioning or negation (Diffloth 1972; Johnson 1976; Kita 1997) is not surprising. \\ The point of providing a depiction is usually to evoke some particular sensory event (actual or imagined), not to \\ not evoke it. \\ 5 The most important exception here is Japanese, where there is a long tradition of native speaker linguists and \\ extensive ideophone dictionaries (Akita 2009b offers a useful bibliography). \\ 6 Adopting a set of distinctions made in Japanese linguistics, Akita (2009a:20-32) proposes a Lexical Iconicity Hier- \\ archy $(\mathrm{LIH})$ that leads from phonomimes (giongo) via phenomimes (gitaigo) to psychomimes (gizyoogo). While similar \\ in some respects, the implicational hierarchy proposed here aims for a finer grain and would accomodate the three- \\ fold Japanese distinction as one language-specific way of slicing up the possibility space.
}

\section{Works Cited}

Ahlner, Felix, and Jordan Zlatev. 2010. Cross-modal iconicity: a cognitive semiotic approach to sound symbolism. Sign Systems Studies 38(1/4). 298-348.

Akita, Kimi. 2009a. A grammar of sound-symbolic words in Japanese: theoretical approaches to iconic and lexical properties of Japanese mimetics. PhD dissertation, Kobe University. [Online]. Retrieved on 10 June 2012 from: http://www.lib.kobe-u.ac.jp/handle_gakui/D1004724.

—. 2009b. A Bibliography of Sound-Symbolic Phenomena in Japanese. Bibliography. Kobe University, May. http: //sites.google.com/site/akitambo/Home/BibA.pdf.

- 2010. An embodied semantic analysis of psychological mimetics in Japanese. Linguistics 48. 1195-220. doi:10.1515/LING.2010.039.

—-, Mutsumi Imai, Noburo Saji, Katarina Kantartzis, and Sotaro Kita. forthcoming. Mimetic vowel harmony. Japanese/Korean Linguistics, ed. by Bjarke Frellesvig and Peter Sells. Vol. 20. Stanford, CA: CSLI Publications.

Alexandre, Pierre. 1966. Préliminaire à une présentation des idéophones Bulu. Neue Afrikanische Studien, Hamburger Beiträge zur Afrika-Kunde, ed. by J. Lukas, 9-28. Hamburg: Deutsches Institut für AfrikaForschung.

Alpher, Barry. 1994. Yir-Yoront ideophones. Sound symbolism, ed. by Leanne Hinton, Johanna Nichols and John J. Ohala, 161-77. Cambridge: Cambridge University Press.

Ameka, Felix K. 2001. Ideophones and the nature of the adjective word class in Ewe. Ideophones, ed. by F. K. Erhard Voeltz and Christa Kilian-Hatz, 25-48. Amsterdam: John Benjamins.

Asano, Turuko (ed.) 1978. Giongo gitaigo ziten [A Dictionary of Sound Manner Mimetics]. Tokyo: Kadokawa.

Awoyale, Yiwola. 1983. On the semantic fields of Yoruba ideophones. Journal of the Linguistic Association of Nigeria 2. 11-22. 
Baronti, David Scott. 2001. Sound symbolism use in affect verbs in Santa Catarina Ixtahuacan. PhD dissertation, University of California, Davis.

Barsalou, Lawrence W. 1999. Perceptual symbol systems. Behavioral and Brain Sciences 22(04). 577-660.

Bartens, Angela. 2000. Ideophones and sound symbolism in Atlantic Creoles. Saarijärvi: Gummerus Printing.

Beck, David. 2008. Ideophones, adverbs, and predicate qualification in Upper Necaxa Totonac. International Journal of American Linguistics 74(1). 1-46.

Blanchard, Yves, and Philip A. Noss. 1982. Dictionnaire Gbaya-Français: Dialecte Yaayuwee. Meiganga: Centre de traduction gbaya.

Blench, Roger. 2010. The sensory world: ideophones in Africa and elsewhere. Perception of the invisible: religion, historical semantics and the role of perceptive verbs, ed. by Anne Storch, 275-96. Cologne: Köppe.

Bloom, Paul, and Lori Markson. 1998. Intention and analogy in childrens naming of pictorial representations. Psychological Science 9(3). 200-4.

Brown, Roger, and Ronald Nuttall. 1959. Method in phonetic symbolism experiments. Journal of Abnormal and Social Psychology 59(3). 441-5. doi:10.1037/h0045274.

Brown, Roger W., Abraham H. Black, and Arnold E. Horowitz. 1955. Phonetic symbolism in natural languages. Journal of Abnormal Psychology 50(3). 388-93.

Burbridge, A. 1938. The use of the ideophone. Bantu Studies 12(3). 234.

Carr, Denzel. 1966. Homorganicity in Malay/Indonesian in expressives and quasi expressives. Language 42(2). 370-7.

Cassell, Justine, and David McNeill. 1991. Gesture and the poetics of prose. Poetics Today 12(3). 375-404. doi: $10.2307 / 1772644$.

Chafe, Wallace, and Johanna Nichols (eds). 1986. Evidentiality: the linguistic coding of epistemology. Norwood, NJ: Ablex Publishing Corporation.

Childs, G. Tucker. 1988. The phonology and morphology of Kisi. PhD dissertation, Berkeley: University of California.

2. 1994. African ideophones. Sound symbolism, ed. by Leanne Hinton, Johanna Nichols and John J. Ohala, 178-204. Cambridge: Cambridge University Press.

- 2001. Research on ideophones, whither hence? the need for a social theory of ideophones. Ideophones, ed. by F. K. Erhard Voeltz and Christa Kilian-Hatz, 63-73. Amsterdam: John Benjamins.

Ciccotosto, Nick. 1991. Sound symbolism in natural languages. PhD dissertation, Florida: University of Florida.

Clark, Herbert H., and Richard J. Gerrig. 1990. Quotations as demonstrations. Language 66(4). 764-805.

Classen, Constance. 1993. Worlds of \Sense. London: Routledge.

Clift, Rebecca. 2006. Indexing stance: reported speech as an interactional evidential. Journal of Sociolinguistics 10 (5). 569.

Collins, J. T. 1979. Expressives in Kedah Malay. South-East Asian Linguistic Studies 4. 379-406.

Crisfield, Arthur Grayson. 1978. Sound symbolism and the expressive words of Lao. PhD dissertation, University of Hawai'i.

Crowther, Samuel Ajayi. 1852. A vocabulary of the Yoruba language, together with introductory remarks by the rev. O. E. Vidal, M. A. London: Seeleys.

Davidson, Iain, and William Noble. 1989. The archaeology of perception: traces of depiction and language. Current Anthropology 30(2). 125-55.

Davis, R. 1961. The fitness of names to drawings. A cross-cultural study in Tanganyika. British Journal of Psychology 52(3). 259-68.

Dhoorre, Cabdulqaadir Salaad, and Mauro Tosco. 1998. 111 Somali ideophones. Journal of African Cultural Studies 11(2). 125-56.

Diffloth, Gérard. 1972. Notes on expressive meaning. Chicago Linguistic Society 8. 440-7.

—. 1976. Expressives in Semai. Oceanic Linguistics Special Publications 13. 249-64.

- 1980. Expressive phonology and prosaic phonology in Mon-Khmer. Studies in Mon-Khmer and Thai Phonology and Phonetics in Honor of E. Henderson, ed. by Theraphan L. Thongkum, 49-59. Bangkok: Chulalongkorn University Press.

—. 1994. i: big, a: small. Sound symbolism, ed. by Leanne Hinton, Johanna Nichols and John J. Ohala, 107-14. Cambridge: Cambridge University Press.

Dingemanse, Mark. 2009. Ideophones in unexpected places. Proceedings of Conference on Language Documentation and Linguistic Theory 2, ed. by Peter K. Austin, Oliver Bond, Monik Charette, David Nathan and Peter Sells, 83-94. London: SOAS, November 14.

- 2010. Folk definitions of ideophones. Field manual volume 13, ed. by Elisabeth Norcliffe and N. J. Enfield, 24-9. Nijmegen: Max Planck Institute for Psycholinguistics. http://fieldmanuals.mpi.nl/volumes/2010/folk-definitions-of-ideophones/.

—. 2011a. The meaning and use of ideophones in Siwu. PhD dissertation, Nijmegen: Radboud University. http://thesis.ideophone.org/. 
. 2011b. Ezra Pound among the Mawu: ideophones and iconicity in Siwu. Semblance and signification, ed. by Pascal Michelucci, Olga Fischer and Christina Ljungberg, 39-54. Amsterdam: John Benjamins.

- 2011c. Ideophones and the aesthetics of everyday language in a West-African society. The Senses and Society 6(1): 77-85. doi:10.2752/174589311X12893982233830.

- forthcoming. Expressiveness and system integration. On the typology of ideophones, with special reference to Siwu. STUF - Language Typology and Universals.

— , and Asifa Majid. 2012. The semantic structure of sensory vocabulary in an African language. Proceedings of the 34th Annual Conference of the Cognitive Science Society, ed. by N. Miyake, D. Peebles and R. P. Cooper, 300-5. Austin, TX: Cognitive Science Society.

Doke, Clement Martyn. 1935. Bantu linguistic terminology. London: Longmans, Green, and Co.

- 1948. The basis of Bantu literature. Africa: Journal of the International African Institute 18(4). $284-301$.

- and Benedict Wallet Vilakazi. 1953. Zulu-English dictionary, 2nd edn. Johannesburg: Witwatersrand University Press.

Donald, Merlin. 2005. Imitation and mimesis. Perspectives on imitation, ed. by Susan Hurley and Nick Chater, 283-300. Cambridge, MA: MIT Press, March.

Dumestre, Gérard. 1998. Les Idéophones: Le cas du bambara. Faits de Langues: Revue de Linguistique 11. 321-33.

Epps, Patience. 2005. A grammar of Hup. PhD dissertation, University of Virginia.

Evans, Nicholas. 2010. Semantic typology. The Oxford handbook of linguistic typology, ed. by Jae Jung Song, 504-3. Oxford: Oxford University Press.

Fordyce, James Forrest. 1988. Studies in sound symbolism with special reference to English. PhD dissertation, Los Angeles: University of California.

Fortune, G. 1962. Ideophones in Shona: an inaugural lecture given in the University College of Rhodesia and Nyasaland on 28 April 1961. London / New York: Oxford University Press.

Frieke-Kappers, Claertje. 2007. The creative use of genre features: continuity and change in patterns of language use in Budu, a Bantu language of Congo (Kinshasa). $\mathrm{PhD}$ dissertation, Vrije Universiteit.

Gasser, Michael, Nitya Sethuraman, and Stephen Hockema. 2010. Iconicity in expressives: an empirical investigation. Experimental and empirical methods, ed. by Sally Rice and John Newman, 163-80. Stanford, CA: CSLI Publications.

Geurts, Kathryn Linn. 2002. Culture and the senses: bodily ways of knowing in an African community. Berkeley: University of California Press.

Gipper, Sonja. 2011. Evidentiality and intersubjectivity in Yurakaré: an interactional account. PhD dissertation, Nijmegen: Radboud University \& MPI for Psycholinguistics.

Gomi, Taro. 1989. An illustrated dictionary of Japanese onomatopoeic expressions. Transl. by J. Turrent. Tokyo: Japan Times.

Goodman, Nelson. 1968. Languages of art: an approach to the theory of symbols. Indianapolis: Bobbs-Merrill.

Güldemann, Tom. 2008. Quotative indexes in African languages: a synchronic and diachronic survey. Berlin: Mouton de Gruyter.

Hamano, Shoko Saito. 1986. The sound-symbolic system of Japanese (ideophones, onomatopoeia, expressives, iconicity). $\mathrm{PhD}$ dissertation, University of Florida.

Henderson, Eugénie J. A. 1965. Final -k in Khasi: a secondary phonological pattern. Lingua 14. $459-66$. doi:10.1016/0024-3841(65)90057-4.

Hinton, Leanne, Johanna Nichols, and John J. Ohala (eds). 1994. Sound symbolism. Cambridge: Cambridge University Press.

Holt, Elizabeth. 1996. Reporting on talk: the use of direct reported speech in conversation. Research on Language \& Social Interaction 29(3). 219-45.

Howes, David (ed.) 1991. The varieties of sensory experience: a sourcebook in the anthropology of the senses. Toronto: University of Toronto Press.

Imai, Mutsumi, Sotaro Kita, Miho Nagumo, and Hiroyuki Okada. 2008. Sound symbolism facilitates early verb learning. Cognition 109(1). 54-65. doi:10.1016/j.cognition.2008.07.015.

Jakobson, Roman, and Linda R. Waugh. 1979. The sound shape of language. Bloomington: Indiana University Press.

Johnson, Marion M. 1976. Toward a definition of the ideophone in Bantu. Working Papers in Linguistics 21. 240-53.

Joseph, Brian D. 1997. On the linguistics of marginality: the centrality of the periphery. Chicago Linguistic Society 33. 197-213.

Junod, Henri A. 1896. Grammaire ronga. Lausanne: Imprimerie Georges Bridel \& Cie.

Kilian-Hatz, Christa. 1999. Ideophone: Eine typologische Untersuchung unter besonderer Berücksichtigung afrikanischer Sprachen. Cologne: Habilitationsschrift, Universität zu Köln.

—. 2001. Universality and diversity: ideophones from Baka and Kxoe. Ideophones, ed. by F. K. Erhard Voeltz and Christa Kilian-Hatz, 155-63. Amsterdam: John Benjamins.

Kim, Young-Seok. 1984. Aspects of Korean morphology. PhD dissertation, Austin: The University of Texas. 
Kita, Sotaro. 1997. Two-dimensional semantic analysis of Japanese mimetics. Linguistics 35. 379-415.

Klamer, Marian. 1999. Austronesian expressives and the Lexicon. Toronto Working Papers in Linguistics 16(2). 201-19.

- 2001. Expressives and iconicity in the Lexicon. Ideophones, ed. by F. K. Erhard Voeltz and Christa KilianHatz, 165-81. Amsterdam: John Benjamins.

. 2002. Semantically motivated lexical patterns: a study of Dutch and Kambera expressives. Language $78(2)$. 258-86.

Klassen, Doreen Helen. 1999. You can't have silence with your palms up: ideophones, gesture, and iconicity in Zimbabwean Shona women's ngano (storysong) performance. PhD dissertation, Indiana University.

Koelle, Sigismund Wilhelm. 1854. Grammar of the Bórnu or Kānurī language. London: Church Missionary House. Köhler, W. 1929. Gestalt psychology. New York: Liveright Publishing Corporation.

Kosslyn, Stephen M. 1980. Image and mind. Cambridge, Mass: Harvard University Press.

Kruspe, Nicole. 2004. A grammar of Semelai. Cambridge: Cambridge University Press.

Kulemeka, Andrew Tilimbe. 1994. The status of the ideophone in Chichewa. PhD dissertation, Indiana University.

- 1995. Sound symbolic and grammatical frameworks: a typology of ideophones in Asian and African languages. South African Journal of African Languages/Suid-Afrikaanse Tydskrif vir Afrikatale 15(2). 73-84.

Kunene, Daniel P. 1965. The ideophone in Southern Sotho. Journal of African Languages 4. 19-39.

- 1978. The Ideophone in Southern Sotho. Berlin: Dietrich Reimer.

2001. Speaking the act: the ideophone as a linguistic rebel. Ideophones, ed. by F. K. Erhard Voeltz and Christa Kilian-Hatz, 183-91. Amsterdam: John Benjamins.

Le Guen, Olivier. 2011. Materiality vs. expressivity: the use of sensory vocabulary in Yucatec Maya. The Senses and Society 6(1). 117-25.

Lee, Jin-Seong. 1992. Phonology and sound symbolism of Korean ideophones. PhD dissertation, Indiana University.

Levinson, Stephen C. 1983. Pragmatics. Cambridge: Cambridge University Press.

Liberman, Mark. 1975. The intonational system of english. PhD dissertation, MIT.

Lydall, Jean. 2000. Having fun with ideophones: a socio-linguistic look at ideophones in Hamar, Southern Ethiopia. Proceedings of the XIV International Conference of Ethiopian Studies, ed. by Baye Yimam, Richard Pankhurst, David Chapple, Yonas Admassu, Alula Pankhurst, and Birhanu Teferra, 886-91. Addis Ababa: Addis Ababa University.

Maduka, Omen N. 1988. Size and shape ideophones in Nembe: a phonosemantic analysis. Studies in African linguistics 19(1). 93-113.

Magnus, Margaret. 2001. What's in a word? Studies in phonosemantics. PhD dissertation, NTNU.

Majid, Asifa, and Stephen C. Levinson. 2007. Language of perception: overview of field tasks. Field manual volume 10, ed. by. Asifa Majid, 8-9. Nijmegen: Max Planck Institute for Psycholinguistics.

— and - 2011. The senses in language and culture. The Senses and Society 6(1). 5-18.

Marks, Lawrence Edward. 1978. The unity of the senses: interrelations among the modalities. New York; London: Academic Press.

McFarland, Teresa. 2009. The phonology and morphology of Filomeno Mata Totonac. PhD dissertation, Berkeley: University of California.

Mester, R. Armin, and Junko Itô. 1989. Feature predictability and underspecification: palatal prosody in Japanese mimetics. Language 65(2). 258-93. doi:10.2307/415333.

Mithun, Marianne. 1982. The synchronic and diachronic behavior of plops, squeaks, croaks, sighs, and moans. International Journal of American Linguistics 48(1). 49-58.

Mok, Waiching Enid. 2001. Chinese sound symbolism: a phonological perspective. PhD dissertation, University of Hawai'i.

Mous, Maarten. 2000. Ka babáy kabábiyo: Riddling in Iraqw. Afrikanistische Arbeitspapiere 62. 39-69.

—, and Safari Sanka. 2007. Sound symbolism in Iraqw literature. Kioo Cha Lugha 5(1). $24-9$.

Mphande, Lupenga. 1989. A phonological analysis of the ideophone in ChiTumbuka. PhD dissertation, The University of Texas at Austin.

- 1992. Ideophones and African verse. Research in African Literatures 23(1). 117-29.

Newman, Paul. 1968. Ideophones from a syntactic point of view. Journal of West African Languages 5. $107-17$.

- 2000. The Hausa language: an encyclopedic reference grammar. Yale: Yale University Press.

- 2001. Are ideophones really as weird and extra-systematic as linguists make them out to be? Ideophones, ed. by F. K. Erhard Voeltz and Christa Kilian-Hatz, 251-8. Amsterdam: John Benjamins.

Noss, Philip A. 1975. The ideophone: a linguistic and literary device in Gbaya and Sango with reference to Zande. Directions in Sudanese linguistics and folklore, ed. by S. H. Hurreiz and Herman Bell, 142-52. Khartoum: Khartoum University Press.

- 1986. The ideophone in Gbaya syntax. Current approaches to African linguistics, ed. by. Gerrit J. Dimmendaal, 3:241-55. Dordrecht: Foris. 
33-43.

- 2001. Ideas, phones and Gbaya verbal art. Ideophones, ed. by F. K. Erhard Voeltz and Christa Kilian-Hatz, 259-70. Amsterdam: John Benjamins.

Nuckolls, Janis B. 1995. Quechua texts of perception. Semiotica 103(1/2). 145-69.

. 1996. Sounds like life: sound-symbolic grammar, performance, and cognition in Pastaza Quechua. New York: Oxford University Press.

- 1999. The case for sound symbolism. Annual Review of Anthropology 28. 225-52.

- 2004. To be or to be not ideophonically impoverished. SALSA XI: Proceedings of the Eleventh Annual Symposium about Language and Society, ed. by. Wai Fong Chiang, Elaine Chun, Laura Mahalingappa and Siri Mehus, 131-42. Austin: University of Texas.

Nuckolls, Janis B. 2006. The neglected poetics of ideophony. Language, culture, and the individual, ed. by Catherine O’Neil, Mary Scoggin and Kevin Tuite, 39-50. München: Lincom Europa.

Okpewho, Isidore. 1992. African oral literature: backgrounds, character, and continuity. Bloomington: Indiana University Press.

Osaka, Naoyuki, and Mariko Osaka. 2005. Striatal reward areas activated by implicit laughter induced by mimic words in humans: a functional magnetic resonance imaging study. NeuroReport 16(15). 1621-4.

Paivio, Allan. 1986. Mental representations: a dual coding approach. New York: Oxford University Press.

Pāninini. 1962. The Asḥtādhyāyī. Trans. Srisa Chandra Vasu. Delhi: Motilal Banarsidass.

Pederson, Eric, Eve Danziger, David Wilkins, Stephen Levinson, Sotaro Kita, and Gunter Senft. 1998. Semantic typology and spatial conceptualization. Language 74(3). 557-89.

Pei, Mario. 1966. Glossary of linguistic terminology. New York: Anchor Books.

Perniss, Pamela, Robin L. Thompson, and Gabriella Vigliocco. 2010. Iconicity as a general property of language: evidence from spoken and signed languages. Frontiers in Psychology 1(227). 1-15.

Potts, Christopher. 2007. The expressive dimension. Theoretical Linguistics 33(2). 165-98.

Ramachandran, V. S., and Edward M. Hubbard. 2001. Synaesthesia: a window into perception, thought and language. Journal of Consciousness Studies 8(12). 3-34.

Reichard, Gladys A. 1950. Navaho religion: a study of symbolism. New York: Bollingen Foundation.

Samarin, William J. 1965. Perspective on African ideophones. African Studies 24(2). 117-21.

. 1967a. Determining the meaning of ideophones. Journal of West African Languages 4(2). 35-41.

1967b. Field linguistics. New York: Holt, Rinehart and Winston.

1969. The art of Gbeya insults. International Journal of American Linguistics 35(4). 323-9.

1970a. Field procedures in ideophone research. Journal of African Languages 9(1). 27-30.

1970b. Inventory and choice in expressive language. Word 26. 153-69.

1971a. Survey of Bantu ideophones. African Language Studies 12. 130-68.

1971b. Measuring variation in the use of Gbeya ideophones. Annales de L'Université d'Abidjan, Ser. H 2. 483-8.

- 1971c. Appropriateness and metaphor in the use of ideophones. Orbis 20. 356-69.

Sapir, Edward. 1929. A study in phonetic symbolism. Journal of Experimental Psychology 12(3). 225-39.

Schegloff, Emanuel A. 2006. Interaction: the infrastructure for social institutions, the natural ecological niche for language, and the arena in which culture is enacted. Roots of human sociality: culture, cognition, and human interaction, ed. by Nick J. Enfield and Stephen C. Levinson, 70-96. Oxford: Berg.

Schiffman, Harvey R. 1990. Sensation and perception. Hoboken, NJ: John Wiley and Sons.

Sekuler, Robert, and Randolph Blake. 2002. Perception, 4th edn. Boston: McGraw-Hill.

Sien, Nam-Cheol. 1997. An autosegmental analysis of ideophones in Korean. PhD dissertation, University of Washington.

Sohn, Hyang-Sook. 1987. Underspecification in Korean phonology. PhD dissertation, University of Illinois at Urbana-Champaign.

Stivers, Tanya. 2008. Stance, alignment, and affiliation during storytelling: when nodding is a token of affiliation. Research on Language \& Social Interaction 41(1). 31-57.

Tedlock, Dennis. 1999. Ideophone. Journal of Linguistic Anthropology 9(1-2). 118-20.

Tufvesson, Sylvia. 2007. Expressives. Field manual volume 10, ed. by. Asifa Majid, 53-7. Nijmegen: MPI for Psycholinguistics. http://fieldmanuals.mpi.nl/volumes/2007/expressives/.

- 2011. Analogy-making in the Semai Sensory World. The Senses and Society 6(1). 86-95. doi:10.2752/ 174589311 X12893982233876.

Van der Auwera, Johan, and Ceyhan Temürcü. 2006. Semantic maps. Encyclopedia of language \& linguistics, ed. by Brown, Keith, 131-4. Oxford: Elsevier.

Vidal, Owen Emeric. 1852. Introductory remarks. A vocabulary of the Yoruba language, ed. by. Samuel Ajayi Crowther, 1-38. London: Seeleys.

Walton, Kendall L. 1973. Pictures and make-believe. The Philosophical Review 82(3). 283-319. 
Watson, Richard L. 2001. A comparison of some Southeast Asian ideophones with some African ideophones. Ideophones, ed. by. F. K. Erhard Voeltz and Christa Kilian-Hatz, 385-405. Amsterdam: John Benjamins.

Wayland, Ratree. 1996. Lao expressives. Mon-Khmer Studies 26. 217-31.

Webster, Anthony K. 2008a. "To give an imagination to the listener": The neglected poetics of Navajo ideophony. Semiotica 171. 343-65.

- 2008b. Running again, roasting again, touching again: repetition, heightened affective expressivity and the utility of linguaculture in navajo and beyond. Journal of American Folklore 121. 482.

- 2009. The poetics and politics of Navajo ideophony in contemporary Navajo poetry. Language \& Communication 29(2). 133-51. doi:10.1016/j.langcom.2008.12.005.

Weiss, Jonathan H. 1964. Phonetic symbolism re-examined. Psychological Bulletin 16(6). 454-8.

Werner, Alice. 1919. Introductory sketch of the Bantu languages. London: Kegan.

Westermann, Diedrich Hermann. 1905. Wörterbuch der Ewe-Sprache. Vol. I. Teil: Ewe-Deutsches Wörterbuch. II vols. Berlin: Dietrich Reimer (Ernst Vohsen).

- 1907. Grammatik der Ewe-Sprache. Berlin: Dietrich Reimer.

1927. Laut, Ton und Sinn in westafrikanischen Sudansprachen. Festschrift Meinhof, ed. by. Franz Boas, 315-28. Hamburg: L. Friederichsen.

- 1937. Laut und Sinn in einigen westafrikanischen Sudan-Sprachen. Archiv für vergleichende Phonetik 1. 154-72, 193-211.

Whitehead, J. 1899. Grammar and dictionary of the Bobangi language. London: Kegan Paul, Trench, Trübner and Co.

Whitney, William Dwight. 1950. Sanskrit grammar. Cambridge, MA: Harvard University Press.

Wundt, Wilhelm. 1922. Völkerpsychologie. Eine Untersuching der Entwicklungsgesetze von Sprache, Mythus und Sitte. Vol 2: Die Sprache, II. Leipzig: Wilhelm Engelmann.

Yankah, Kwesi. 1984. The Folktale as "True" Experience Narrative. Folklore Forum 17(2). 220-9.

Yeung, H. Henny, and Janet F. Werker. 2011. Lip-shapes achieved while chewing and sucking affect audiovisual speech perception in infancy. Paper presented at the biennial meeting of the Society for Research on Child Development, March, Montréal.

Zemach, Eddy M. 1975. Description and depiction. Mind 84(336). 567-78.

Zwicky, Arnold M., and Geoffrey K. Pullum. 1987. Plain morphology and expressive morphology. Proceedings of the Thirteenth Annual Meeting of the Berkeley Linguistics Society, ed. by John Aske, Natasha Beery, Laura Michaelis and Hana Filip, VII, 330-40. Berkeley: Berkeley Linguistics Society. 